\title{
NEWSPAPER "KOMPAS" IN INDONESIAN POLITICAL CONSTELLATION (1960-1980)
}

\author{
Apri Damai Sagita Krissandi \\ Sanata Dharma University \\ apridamai@gmail.com \\ DOI: https://doi.org/10.24071/ijhs.2018.010207 \\ received 22 November 2017; revised 30 December 2017; accepted 1 February \\ 2018
}

\begin{abstract}
This study aims to describe the situation experienced by Kompas newspaper in the context of Indonesian politics from 1960 to 1980. This method of this research is a qualitative descriptive study describing an event with a historical approach. The method used is critical discourse analysis by reviewing the editorial from Kompas newspaper from 1960 to 1980. From the research result, it was found that Malari incident (fifteenth of January 1974) was the starting point of Kompas during the New Order era. Kompas is considered an idealist newspaper, Kompas which expresses people's conscience and aspirations, boldly and critically exercises social control. The pre-Malari Kompas is a free, independent and articulate newspaper. On the contrary, post-Malari Kompas is a less idealist newspaper, which tends to represent the interests of the rulers, government or even the state which never exercise social control critically, decisively, and courageously. The post-Malari Kompas is a newspaper that is not free or at least a newspaper that has a very limited independence.
\end{abstract}

Keywords: Kompas, newspapers, Malari, the new order

\section{Introduction}

Kompas was first published on June 28, 1965, in Jakarta. The founders of Kompas are PK. Ojong, Jacob Oetama and several other journalists of former Digest magazine workers. Before occupying the office at the printing PT. Kinta, the editorial crew and Kompas journalists do journalistic activities at Jacob Oetama's home. The emergence of Kompas was not separated from the political constellation of that time, where Sukarno was incessantly implementing the Politics of Guided Democracy. One of Soekarno's policies at the time was the party's monopoly in the socio-political life of the community, including in the world of the press. By Presidential Regulation no 6 of 1964, the press is required to indulge in one political party.

The cold war between the Communists and the Army also encouraged the birth of Kompas. Recognizing the dangers of the Communists, Lt. Gen. Ahmad Yani as the Minister of the Army Commander expressed his idea to Frans Seda as Minister of Plantation to issue a bold newspaper against the Communists. Frans 
Seda then contacted I.J Kasimo from (Parkindo) and two managers of the Essence of P.K Ojong and Jacob Oetama.

At first, the newspaper was published and named Bentara Rakyat. But on the political grounds that the word "people" had been manipulated by the Communist movement and as if it were a Communist term, it was named Kompas. According to Soekarno, the name Bentara Rakyat means the guard of the people, but it was felt less clear to explain the vision and mission of the pioneers. The word "Kompas" stated more clearly the purpose of the direction as a pointer. Bentara Rakyat then enshrined as the name of the foundation that shaded Kompas. The board of Bentara Rakjat Foundation is I.J. Kasimo (Chairman), Frans Seda (Vice Chairman), F.C. Palaunsuka (Author I), Jakob Oetama (Author II), and Auwjong Peng Koen (treasurer).

When pro-communism was popular, Kompas was born and went against the mainstream. In addition, Kompas is accused as a mouthpiece of Catholics (which gave rise to Kompas's ridicule as an abbreviation of the Father's Command). On 28 June 1965, the first print of Kompas was published. After the first three days, the actual Kompas circulating. The first issue of Kompas consists of 11 foreign news and 7 domestic news. The introductory edition at the bottom right also includes a tagline: "Let's start tying the heart today with Mang Usil".

The editorial that is the attitude of the newspaper has not been raised by Kompas, but on page two there is a writing about the birth of Kompas, which became known as Kompas's header. On page two there is also some news both inside and outside the country, some freelance articles. While the new sports news gets a very small share on page four. The ads only numbered six and occupied less than half a page.

At the end of the period of guided democracy and the emergence of the New Order, Kompas was directed to become independent and general. This decision is based on the consideration that the public vision of the newspaper should be open. Such vision and attitudes are considered in accordance with the function of the Indonesian press, namely to develop mutual understanding in a fattening society. With this openness is expected Kompas able to grow rapidly.

When the events of September 30, 1965, the Kompas managers were forced to take decisions at the most crucial moment. The new coup d'etat issued a provision, every published newspaper must declare loyalty to the coup attempt. PK Ojong tells Jacob Oetama that if Kompas declares loyalty is a foolish act. If the Kompas is about to close at any time, it will have the same effect on their publication.

This choice was proved to be true because the efforts of the PKI (communist party of Indonesia) failed miserably. On October 1, 1965, the Regional Warling Authority (Peperada) issued an instruction to close all newspapers to calm the social and political situation. Only two media that are published are Yudha News of Armed Forces and Antara. This instruction is also intended to allow Pepelrada time to verify which papers are pro and contra against the PKI and the 30 September movement.

Finally on October 6, 1965, all the newspapers that never declared loyalty to the effort may come back. This is a blessing in disguise for Kompas. In the midst of the information vacuum, people do not have much choice to buy newspapers, 
causing the Kompas to increase in the circulation significantly and reach 23,268 copies.

The hegemonic theory is important in this analysis because the hegemonic theory helps to uncover the constellation of power presented in the Kompas editorial. Through hegemonic theory the researcher analyse the forms of hegemony, the cause of hegemony, and the impact of state hegemony.Ideology in its broadest sense is a conception of a world that implicitly manifests itself in art, law, economic activity, and in individual and collective life. The function of ideology is the preserver of the unity of the whole social bloc, as a cement and a unifying tool between the truly opposing social forces. In practice, this ideology is defined by intellectuals in the task of carrying out formal and intellectual reforms. The task is not in the empty space.

The nature of the ideological struggle is not entirely from the beginning. The struggle is the process of transforming some elements to be rearranged and combined in different ways with a new core or principal principle. The ideological system cannot be made once so as a type of intellectual construction undertaken by political party leaders. It must be confronted and gradually built through political and economic struggles and its character will depend on the relationships of the various forces that existed during the time when it was built.

According to Simon, Gramsci uses the term equivalent to ideology of culture, philosophy, worldview, or moral and intellectual reform. Ideology is included in the superstructure. Furthermore, in Gramsci's view there are four stages of ideology: elements of consciousness, material elements, elements of identity solidarity, and elements of freedom.

The element of consciousness implies that the ideology of giving matter is human to move and gain awareness of their position in the economic, political, social, and struggle to become a hegemonic class. The starting point of the element of consciousness is the common sense of a person who is uncritical and unconscious to the world. Common sense comes from various sources and past events that make society accept custom, power, injustice, and oppression as a natural thing, the product of natural law, the will of God, and can not change. Common sense is where the dominant ideology is built, the place of resistance and ideological opposition.

The material element, at the ideological stage will be tangible. The existence of ideological material material is seen in various practical activities and incarnate in the whole way of collective life of society. Ideology is not just an idea in the clouds, but it has its material existence in many practical human activities. Human practical activities include the way of life of societies, institutions and social practice organizations, namely political parties, trade unions, others in civil society, state apparatus, commercial enterprises, or financial institutions.

The element of solidarity identity is ideology which is successfully accommodates the interests of various subaltern classes. Ideology has been able to bind as the foundation of social unity, different social groups in one container. Because embracing the various social groups, in the unification of new ideologies, does not have to remove all the different ideological systems but instead transforms the ideologies that defend and rearrange some of the most formidable elements. 
An element of freedom is the highest stage that can be achieved by an ideology. At this stage one becomes aware that his or her corporate interest, in the present and future development, overcomes the corporate boundaries of a purely economic class, but reaches into another subordinate group. With this awareness (in common sense) society is directed in an attempt to give a great opportunity in this process because human beings are subject or facts that change history.

According to Gramsci, ideology is more than just an idea system. He distinguishes between the arbitrary systems proposed by certain intellectuals and philosophers, and the historical organic ideologies, the ideologies which are necessary under certain social conditions: "as long as ideology is historically necessary, it has a psychological validity: "ideology" governs human beings and provides a place for humans to move, gain awareness of their positions, their struggles, and so on. " From the above argument, the researcher attempts to analyze Kompas's editorial between 1966 and 1980 using Gramsci's hegemony theory.

\section{Method}

This research uses a qualitative approach. While the method used is content analysis or content analysis. The author also uses critical discourse analysis methods. The critical discourse analysis hereinafter referred to as CDA is used to express the relationship of science and power. In addition CDA can be used to criticize. CDA is also used to describe something, translate, analyze, and criticize the social life that is reflected in text and speech. CDA deals with the study and analysis of texts or speeches to denote a discursive source of power, power, inequality, injustice, and prejudice. The researcher analyzed the 15 editorials of Kompas newspaper, between 1966 and 1974. The editorial of the sample is as follows: 1) Kompas, January 7, 1966 entitled Scarcity of Goods and Rising Price of Basic Substances; 2) Kompas, May 5, 1967 entitled Criticism Not Perongrong; 3) Kompas, 27 May 1967 entitled Eliminating Misunderstanding Corruption; 4) Kompas, 7 April 1970 entitled Interference in the PNI ?; 5) Kompas, March 22, 1971 entitled Sequence of the Candidates; 6) Kompas, March 30, 1971 entitled Political Structure of Renewal; 7) Kompas, January 11, 1974 entitled Hope Reasonable Government Only; 8) Kompas, January 22, 1974 entitled Integrity of National Leaders; 9) Kompas, January 26, 1974 entitled Description Puspen Hankam; 10) Kompas, January 15, 1974 entitled President's Appeal; 11) Kompas, April 29, 1974 entitled Control by the Press; 12) Kompas, January 15, 1974 entitled Appeal Do not Strike; 13) Kompas, August 20, 1974 entitled President Soeharto on Illegal Drawing; 14) Kompas, November 16, 1974 entitled Law and Power; and 15) Kompas, December 20, 1974 entitled Development of Psychology.

The data collection techniques are consisted of six steps: (1) browse through and read over and over the editorial, (2) look for the hegemonic facts contained in the editorial, (3) find the source of the literature of the historical document, or the news of the Malari event (Malapetaka 15 January), (4) find the ideologies in the editorial, (5) analyze the ideologies in the editorial using critical discourse analysis method, and (6) write down the results of research. The data analysis procedure used in this study is based on the critical discourse analysis model of Norman Fairclough. The study procedure was modified into six steps: critical- 
creative reading of the data source, the identification of data is hegemony in the editorial, the presentation of the data has been identified, the interpretation of meaning, the inference of meaning, and the presentation of processing results.

\section{Findings and Discussion}

\section{Kompas Ideology: From Populism to Bureaucratism (1966-1980)}

At the beginning of the reign, the New Order had inherited a hypereconomic crisis that reached an alarming peak. Therefore, the New Order rulers undertook a massive and drastic stabilization effort and economic rehabilitation. This program, on the one hand, succeeded in reducing hyper-inflation, but on the other hand, generated a new crisis in society. For the press, this loss is felt when subsidies on the price of newsprint are removed. This situation is exacerbated by the increase in production costs and printing costs (Agassi in Abar, 1995, p.47).

An illustration of the circumstances experienced by the newspaper at that time in the crisis situation was written by P.K. Ojong in Kompas daily, November 3, 1966, which contains about the cessation of government subsidy to the price of newsprint and the rising cost of production and printing resulted in daily price increase Kompas. P.K. Ojong would like to thank the customers of Kompas daily who can understand the phenomenon.

Nevertheless, in the early period of the rise of the New Order, the ruler viewed and treated the non-anti-communist press as his partner of power. Publication efforts by exploiting all the brutality, brutality and fraud of the PKI against its political opponents, especially the generals or high-ranking officers. Likewise, press publications or press releases concerning Sukarno's beliefs, such as Subandrio, Omar Dhani, and Jusuf Muda Dalam, by exposing all their political and economic crimes (Abar, 1995, p.65).

In contrast, the non-anti-communist press also acquired a struggling partner against one of its main enemies, the PKI. Therefore, in the first years of the New Order revival, the press gave a positive reception for the Army's particular political movement and the military in general. This can be seen from the postpress epithets for them, for example, Kompas gives the military nickname as the savior (Abar, 1995, p.67).

After the PKI and the Guided Democracy regime collapsed, perceptions, attitudes and the treatment of New Order rulers against the press began to change. This is mainly due to two critical factors that are mutually supportive. First, the power of the New Order grew stronger and bigger after the Guided Democracy regime collapsed. No more obstacles or political opponents of the Army or ABRI in general or paved the way of his power, except in himself (Crouch in Abar, 1995, p.68)

Secondly, since 1966, the Indonesian press began to be critical of the New Order's power, primarily aimed at the phenomenon of corruption within the bureaucracy of the New Order State, which began to grow and multiply. Even some daily, directly or indirectly, accused some officers close to President Soeharto of corruption. The two factors above made the New Order regime more cautious of the press and began to take anti-press actions, such as appeals or warnings to keep the press more compromise in criticizing the ruler. In addition, the ruler also began to do self-introspection as a positive reaction from the criticism of the press against him. 
In 1966, along with the rise of student movements and protests, populism and press-like stance began to be apparent, as he responded to public grievances over the severe economic crisis in early 1966, in particular, the problem of scarcity of goods and rising prices of goods and the rise basic necessities, Kompas including the press which is critical of the government:

... Neither do we, especially those folk leaders know whether what today is living among the people. So it is appropriate to take the steps of wisdom.

Things that worry about the crowd now is certainly about the rise in prices of basic needs. It's a real fact and we feel it ourselves. The price increase was partly due to government action in the form of formal tariff increases in some areas and prices of some goods.

Of course, the intention of the government to do such a drastic action is, in order to alleviate the life of all of us. If now the increase is expected to be temporary in terms of this transition. However, in fact, the follow-up actions of the implementation of Presidential Decree no. 22 that, make people become restless .... (Kompas, January 7, 1966).

In addition to the critical, can be seen from the example above titles, the element of courage in complaining in Kompas complaints and demands to the government hard. The critical attitude of the Indonesian press intensified in 1967. This critical attitude of the press was manifested, especially in two respects, firstly criticizing and criticizing the increasingly phenomenal graft activity in the state bureaucracy, both expressing critical and creative support for the newly emerging New Order government.

The criticism of the press against corruption among the officials of this State, made President Soeharto go awry. On the one hand, he wants to meet the demands of the people to eradicate corruption firmly in order to maintain the authority of his government. Meanwhile, on the other hand, by eradicating such corruption means his government has dared to "cut himself," in the sense that Suharto will crack down on those around him (Abar, 1995, p.90).

But among the top officials of the State emerged a negative reaction to the press criticisms that were considered outspoken, unscrupulous and disrespectful, so they were said to have undermined the legitimate government. In relation to that came back the reaction from the press, especially Kompas.

\section{Criticism Not Hurt}

... As a democratic institution, the function of the press is no different from other democratic institutions that are: to bring the voice of the people, to exercise control, criticism, and correction on any form of violence so that power is always beneficial for the implementation of the welfare of the community.

We want to affirm again, the purpose of such a function of the press is positive. To keep the power from being abused. In order for that power to reach the right target, namely to realize the welfare of the people.

Then it is clear that by its very nature, the control, criticism, and correction of the form of power is not to undermine the holder of power, but to help that power remain authoritative because it is carried out to achieve the right objective ... (Kompas, May 5, 1967). 


\section{Eliminating Misunderstanding Corruption}

... Misunderstandings increasingly arise when some ABRIs will be targeted against this corruption eradication effort. Intentionally we emphasize the word WRONG in this case.

Because of both sides then there is a dark power that takes generalization tactics. The goal of eradicating corruption is not military or civilian. The general goal is corruptors.

These corruptors are found in civilian groups as well as in the military. The eradicated is not a class or force, which is eradicated corrupt elements of any party without generalization attitude.

Why is it that ABRI is targeted? Above the suede in arguing that it is not true at all.

Not ABRI, but some people in it .... (Kompas, 27 May 1967)

The press criticism of the New Order government with regard to the increasing corruption in the state bureaucracy and the demand that the government is more indifferent and serious in combating and prosecuting its perpetrators indiscriminately did not diminish the press sympathy of the newly created New Order government. The press still provides support. However, the support is, of course, critical and creative.

The development of the critical attitude of the press from year to year increasingly shows improvement. This attitude is manifested in various demands, criticisms, criticisms, and praise to various parties, especially to the government, to the various social, economic and political issues that occur. These demands, criticisms, and criticisms are presented boldly, firmly, to the point, and without hesitation. However, in 1969, the conducive atmosphere between the press and the rulers had begun to crack. This is indicated by the start of the "anti-press" movement by the New Order government.

A number of regulations began to emerge and some of the press was brought to justice for allegedly insulting government officials or legitimate governmental powers. However, this did not diminish the critical attitude of the press to the various social, economic and political events of the day. Even the main elements of the country's political power, namely the military, in 1969 received considerable attention and criticism from the press, especially Kompas. After that, corruption issues began to spread again and many critical actions were done by students and responded by the press. Therefore, in 1970 President Soeharto established a commission 4 whose function was to eradicate corruption. The Indonesian press in 1970 was also partly concerned with criticizing the political actions of the New Order government which had intervened in the internal affairs of various socio-political organizations of society. For example, government intervention against party parties such as PNI (Partai Nasional Indonesia), Parmusi, Persahi, IDI, and PWI. As written Kompas as follows.

\section{Interference in the PNI?}

... interference from outside, let alone from rulers, into party autonomy, temporarily seems to benefit the ruler. But it actually harms him. He will create intrigue within the party. The ambitious, irresponsible people get the channel. They will not hesitate to credit their own colleagues in front of the authorities. Is it such 
a healthy party? The healthy political life that will itself be influenced by unnatural party intrigues ... (Kompas, 7 April 1970)

The attention of the Indonesian press in 1971 was largely focused on electoral issues, from preparation, implementation to the issue of socio-political implications of elections. Kompas also included the most vocal on the issue of the election. The election that took place in July was the first election and organized by the New Order government. Therefore, this election is very important for the New Order government to seek popular support and to gain or to strengthen the political legitimacy of its power. It is in this context that the New Order government is very concerned to win the socio-political organization that represents its political aspirations and the interests of its power. The enormous ambition of winning elections for its socio-political organization made the New Order government use all means, including forced and intimidation. Excesses cannot be avoided.

For the press, the "catastrophe" that struck before the 1971 election was due to some restrictions on the giving and commenting of the press, especially in the quiet week, on certain political issues. Even Kopkamtib (Command of Operations Restoring Security and Order) threatened to close the newspaper that had violated the calm week terms set by the Election Institute (LPU). This Kopkamtib threat really proved to be a reality with the prohibition of two newspapers of the capital, Duta Masyarakat and Kami daily, for one day on July 3, to coincide with election day. Both of these newspapers are banned for violating electoral provisions set by the government.

In the political conditions ahead of the hot election, along with some regulations on the press, the critical attitude that has developed since 1966 has been maintained by the Indonesian press. Kompas is one of the dailies that has a critical attitude to the phenomenon of the election.

\section{Candidate Sequence}

... if the divisions of the parties by the electorate are regarded as the inability of parties to fight for their aspirations, namely the improvement of fate, as its leaders seize their own seats (for example), perhaps the electorate then seeks other alternatives. In this case, the Golkar party, for example, may then be another alternative. But if voters perceive the breakup among the parties is what makes it, the voters can behave in two ways: being indifferent or even being fanatical towards their party ... (Kompas, March 22, 1971).

\section{Renewal of Political Structure}

... We do not question, people agree or not with Golkar. Objectively, however, it must be acknowledged that Golkar contains concrete political reform. Objections that we hear may not even be about the purpose but about the ways. The ways are thought to be accompanied by excesses that can become a system and therefore endanger the renewal business itself. What are people's objections to the process of reforming the political structure through Golkar? Miscellaneous, as far as we can catch. First on the ways that are considered too bulldozer style, too less elegant, contains the elements of coercion. There are other concerns. Soldiers to play a role in Golkar, too dominant ... (Kompas, March 30, 1971). 
The year 1973 was a hot year, a year of concern, where demands on the need for equitable distribution and concern for social justice were increasingly voiced, and so did the development strategies, aid and foreign capital (especially capital from Japan), as well as corruption and state deviation. Meanwhile, the reaction to the demands of society, including the press, was becoming increasingly negative, repressive and harsh from the New Order government.

The public demand for equitable development and social justice voiced the press critically and courageously. Similarly, criticism and criticism of the development strategy, aid, and foreign capital, indigenous and non-indigenous, as well as corruption and misappropriation of state money, are expressed in a critical and bold way. This shows that the press at that time was not affected by the negative, repressive and harsh reaction of the New Order government.

The climax is the occurrence of Malari events. One of the aftermaths of the Malapetaka January 15 (Malari) 1974, was the banning of 12 Indonesian press, a major disaster for the Indonesian press during the New Order government, as well as the rise of the bureaucratic and rhetorical-normative nature of the Indonesian press. It is in this context that the Malari event becomes a demarcation boundary between the populist press and the elite-bureaucratic press, and between the critical press and the rhetorical-normative press.

In the days leading up to the Malari incident, the Indonesian press is still critical. For example, in the headers derived by the following Kompas daily:

\section{Hope The Government Is Fair}

... The suggestion to live according to social reasoning would not have been possible without the efforts to combat corruption. And corruption is easy, because of its disheveled acuteness, as well as the depletion of social consciousness.

The rules to limit the entry of luxury goods would be useless if the lamas were still going on. Especially if the official voices to stem all sorts of luxuries is just to 'calm' and 'cool down' the current public turmoil.

... It was put forward to simply remind the government to remain natural in its efforts to fight against its current luxury. No need to overacting! .... (Kompas, January 11, 1974).

A few days after the Malari incident, especially after a number of newspapers in banned, the populism and critical attitude of the press began to fade. The further drawn in advance of the Malari event, the more obvious the process of fading populism and the critical attitude of the press will be, and the more obvious the process of eliciting-bureaucratic and rhetorical-normative will be enhanced. The press shows more support and approval of any policy made by the state and prefers to cite the political rhetoric of high-ranking state officials to be underlined, affirmed and strengthened. There has never been any criticism, criticism or protest from the press against the policies made by the State or against the rhetoric and political actions of high officials of the state deemed incompatible with the will and aspirations of the people. In other words, the post-Malari Indonesia press is an affirmative press (Abar, 1995, p.153).

Kompas does not include banned newspapers. Therefore, the critical attitude that was initially shown by Kompas began to fade and even became elasticallybureaucratic and rhetorical-normative. The result of Tjipta Lesmana's research on 
daily Kompas concludes that Malari event is a "milestone" for the change of orientation of Kompas daily editorial. Prior to Malari, Kompas was still idealistic and "voicing the conscience of the people" and exercising social control critically and courageously. According to Tjipta Lesmana, his function as a bulldog (watchdog) changed drastically into a "spokesman" or interpreter of a government official statement (Abar, 1995, p.3). This can be seen from Kompas's editorial after the Malari incident.

\section{Integrity of National Leadership}

... To the PWI central board, for two and a half hours on Monday, President Soeharto declared his judgment on the progress of the situation.

He also blurted out his allegations, rumors and press coverage concerning the President's family. Particularly related to Tien Soeharto's mother relationship with various companies, such as Astra, PT Sahit, Bogasari and Batik Keris ...

We who listen directly to the President's statement, draw conclusions, the information is honest, what it is. In place, we all believe in the integrity of national leadership.

The Integrity of National Pinpinan is important, now there is no doubt, even the traces, but surely, the President will continue to clear up the presidential environment and eradicate the misconduct that society hopes ... (Kompas, January 22, 1974).

\section{Description Puspen Hankam}

... In connection with the occurrence of arrests, Brig. Gen. Sumrahadi, Head of the Hankam Information Center provided the press release. The information according to our judgment is correct and relieves the public.

Described, the detentions were aimed at those suspected of being activists of the 15 th and 16th January events as well as the perpetrators of arson and bombing. It is hoped that people should not be restless because the detentions aim to educate them, especially the younger generation to be responsible for the actions they take to explore the background of the event.

But furthermore, as confirmed by the spokesman Hankam, the principle of law is still implemented. The certainty of law is still enforced. Therefore, the public need not be restless ... (Kompas, January 26, 1974)

\section{President's invitation}

... So it is no exaggeration what the President, Repelita II affirmed that the first year we will soon enter into a development that is characteristic and aimed at populism, which has to mean for every person and the whole society, which calls for the responsibility of every person and all of the society. And the light will also be more enjoyed by everyone and the whole community .... (Kompas, January 15, 1974).

\section{Control By Press}

... When accepting the head of the national news agency Antara, Secretary of State Secretary Soedharmono SH explained that the government expects social control from the press, because it also helps the government in carrying out its duties, especially in the field of development at that time.

Affirmed, should not the public opinion, the government does not want to be criticized. The government expects the existence of constructive and fact-based criticisms. 
He added that incitement, slander and untrue news will only lead to chaos and this situation hampers the development of our society ... (Kompas, April 29, 1974).

\section{Exclamation Do Not Crash}

... On Thursday 13 June, Major General G.H. Mantik as Laksus Pangkopkamtibda Jaya issued an appeal. The contents call for the attention of the workers so that they do not strike. The strike will be held accountable.

Before the call came out, the All-Indonesia Workers' Federation issued a statement of its contents warning the workers who acted wildly ...

Understandably, if the security responsible person issues an appeal to the workers not to engage in illicit acts, such as strikes.

If workers are prohibited from striking, it does not mean that their interests are neglected or should not be fought. The opposite should be, since striking and illegal acts are forbidden, so that their interests are fulfilled as far as possible, in order that the prohibited steps, need not be taken .... (Kompas, January 15, 1974)

\section{President Soeharto on Illegal Drawing}

... For the duty of serving the community, civil servants receive no direct service rewards from the communities they serve. The obligation to provide remuneration from the public served, if any, shall be provided to the State in the form of taxes, user charges, fees and so forth, which constitutes the acceptance of the State.

Thus the assertion of President Soeharto is poured in the last pages of his freshness in front of the siding of the House of Representatives last August 15.

We are very relieved to hear President Soeharto's words. Moreover, this effort accompanied the order to stop all kinds of illegal and illegal charges under any pretext. And that every government agency makes a plan and takes concrete action to dismiss the situation ... (Kompas, August 20, 1974)

\section{Law and Power}

... Between, November 12, the General Attorney General Ali Said SH attended the ceremony of the handover of the Chief Prosecutor of South Sulawesi. Among them, the Attorney General shows the difference between law and power.

He said law enforcement is not the same as the enforcement of power, because the main target of law enforcement is justice, while the main target of power is submission.

The attorney general's affirmation we consider important .... (Kompas, November $16,1974)$

\section{Development of Psychology}

... On Sunday 15 December, President Soeharto inaugurated the Palagan Ambarawa monument. In his address, the President explained that the construction of monuments is part of development. That is psychological development.

We are then reminded of the principle of development formulated in the GBHN, is the principle of balance ...

The road of development will be easier if only material prosperity becomes the only guideline. Not cultivated as well as welfare. Therefore, the development that only wants to achieve prosperity, no need to question the way.

Because it holds to the principle of balance, then it must also consider the way we build. On the contrary, only questioning the way, also not hit. We can remove in place without producing concrete improvements for the life of the masses .... (Kompas, December 20, 1974). 
From some of the above editorials and research, the press in general and the Kompas in particular, it can be said that the Malari incident was the "water limit" or the starting point of press performance during the New Order period. The preMalari press is an idealist press, a press that voices conscience and people's aspirations, a bold and critical press exercises social control. The pre-Malari press is a free, independent and articulate press. In contrast, the post-Malari press is a press that is not or less idealistic, tends to "represent" the interests of the ruler, government or state and rarely even never exercise social control critically, decisively and courageously. The post-Malari press is a non-free press or at least a press with very limited independence. The post-Malari press performance in the 80 s to the present has yet to show any fundamental change. The press still tends to be a government release.

In this sphere, Kompas participated intervened by the Malari incident. The threat of banning is one of Kompas starting points in its ideological change. Kompas which originally ideology humans and be critical to government performance as if silenced, changed drastically become elite-bureaucratic. The voice of ordinary folk used to decorate the Kompas daily turned into a bureaucratic elite voice containing government policies. Ironically, the policy does not necessarily support the people, it can be possible as the legitimacy of power alone. Kompas is like a tiger that loses its fangs. Kompas continues to survive with the changed drastic ideology.

\section{Relation of Kompas with State}

Discussions about the press cannot be separated from the interests behind the press, especially the importance of the information submitted. In the development of the latest press, there are at least two major interests behind the press, namely economic interests, and power interests, which make up the content of the press, the information presented, and the meaning it offers. Between these two interests, there is a more fundamental importance that is neglected, namely the public interest. The press that should serve as a public space, caused by the above interests, just ignores the public interest itself.

The strength of economic interests and political power is what really makes the press cannot be neutral, honest, fair, objective and open. As a result, the information presented by the press has raised the issue of serious objectivity of knowledge in the press itself. Economic interests and political power will determine whether the information conveyed by a press contains false truths and truths; conveys objectivity or subjectivity; neutral or aligned; presenting facts or twisting facts; describe reality or simulate reality (Piliang, 2005, p.214).

The public and society, in general, are among the two main interests of the press, which make them a silent majority, who have no power in establishing and deciding information in their own public sphere. On the one hand, when the public sphere is dominated by information politics, which makes information as a political force, the press is transformed into an extension of the ruling power by controlling the public sphere, such as the New Order press after the Malari incident of 1974. On the other hand, when it is controlled by the economy political information, information into a tool of interest to seek profits as much as possible by exploiting the public, as a basic principle of capitalism (Piliang, 2005, p.214). 
It is not surprising that the Indonesian historian and politician Benedict $\mathrm{R}$. O'G Anderson of Cornell University, who writes quality books on nationalism and Southeast Asia, among others Java in a time of revolution: occupation and resistance 1944-1946 and Imagined Communities: Reflections on the Origin and Spread of Nationalism, saw the critical role of Kompas. Anderson calls Kompas a very New Order newspaper (New Order's newspaper excellence). Kompas is very compromised with President Soeharto's regime. The pressure of the Soeharto government was very effective in Kompas, resulting in a careful style of writing. That is the strategy of Kompas to get around the hegemonic power of the New Order, in order to survive, as well as to save thousands of employees who become dependents. However, it is perfectly legitimate if Benedict Anderson interpreted that strategy was a sign of the Kompas' submission to the New Order's power.

Newspapers as an institution have advantages, as well as weaknesses. Weaknesses that can easily be captured when compared to the advantages and weaknesses of people with an institution. People tend to be freer, more clever, fresher, more adept. Institutions cannot be separated from the bureaucracy, tend to be slow, tend to be a lot of considerations and obstacles, tends not too agile capture actuality and catch it as well (Oetama, 2001, p.197). In the New Order government, the press was always confronted with a licensing mechanism, SIUPP, a Press Publishing Business License. The mechanism is actually one of the state's efforts to hegemonize the press. The following three reasons can explain it: the dependence on licensing, the right to grant the license is the state, and the dominance of the state. The state appears as the only one capable of giving the right to the press business. If the state's will is not obeyed, the country is the one holding the decision to revoke the Press Publishing Business License. Therefore, the press is politically powerless and also meaningless in terms of capital.

\section{Conclusion}

In public relations with the state, the press is in a position between the two. The press does not belong entirely to society, but it also does not belong entirely to the state, so the press acts as mediation. The only area that cannot be managed by the state directly is the press (print media). None of the newspapers published and managed by the state are successful journalistically and economicallyfinancially. According to Piliang (2005, p.366), the existence of the press is exactly in the middle, both as a place and as an interest, then the press becomes important for both. The position of the press is considered harmful to the state. When in a major political change, the press is capable of impacting the country almost unexpectedly. That's when the press becomes powerful and has power. Such a press position has several functions. The first function, the press increases the imagination of those in charge of power, enhances the imagination that if not controlled, then the press will be used by others to criticize its power. The second function, the press increases the imagination of the non-powerful, the imagination of the person represented by the press. The third function is to increase the imagination of the press itself, that he is the representative of the people, the representatives of the little people, and so on. Increased imagination in such complexity, is indeed the dynamics of the press work. That is, on the one hand, 
the press is facing a very large kind of power that is essentially incapable of being opposed by the press itself. On the other hand, the press feels the power to urge or force the power to follow his voice.

\section{Reference}

Abar, A.Z. (1995). 1996-1974: Kisah pers indonesia. Yogyakarta: LKIS.

Bourchier, D. (2007). Pancasila versi orde baru. Yogyakarta: Aditya Media.

Budiman, A. (1995). Kebudayaan Materialisme, Egoisme, dan Persaingan (MEP) serta cara menangkalnya. Dalam Suryana, A.S (Ed), Demokrasi dan budaya mep (materialisme, egoisme, dan persaingan). Jakarta: Bina Reka Pariwara.

Hanazaki, Y. (1998). Pers terjebak. Jakarta: Institut Studi Arus Informasi

Herianto, A. (1998). Masihkah politik jadi panglima? Politik kesusastraan indonesia mutakhir. Jakarta: LP3S.

Liddle, R.W. (1992). Partisipasi dan partai politik. Jakarta: PT Temprint.

Luwarso, L. (1998). Wajah media massa kita. In Sutrisno,E (Ed), Reformasi media massa. Jakarta: Aliansi Jurnalis Indonesia.

Oetama, J. (2001). Pers Indonesia. Jakarta: Gramedia Pustaka Utama.

Piliang, Y.A. (2005). Transpolitik: Dinamika politik di dalam era virtualitas. Yogyakarta: Jalasutra.

Pujiharto \& Dewojati, C. (2001). Ideologi cerpen-cerpen koran di Yogyakarta (Research report of Research Institute of Gadjah Mada Univeristy).

Sudjatmiko, B. (2000). Represi melalui media massa pada masa Soeharto. In Dedy, N \& Hidayat (Eds), Pers dalam revolusi mei runtuhnya sebuah hegemoni. Jakarta: PT. Gramedia Pustaka Utama. 